\title{
Differences in the soil seed bank of a mining area and its surroundings: a case study inserted in the Cerrado domain
}

\author{
Felipe Santana Machado ${ }^{1,2,3 *}$ (D), Aloysio Souza de Moura' (D), Ricardo Rabinovici Trotta ${ }^{1}$ (D), \\ Ana Cristina Magalhães de França ${ }^{4}$, Rubens Manoel dos Santos' ${ }^{1}$, Rosângela Tristão Borém ${ }^{4}$ (D), \\ Marco Aurélio Leite Fontes' ${ }^{1}$ (1) \& Luiz Roberto Guimarães Guilherme ${ }^{5}$ (i)
}

\begin{abstract}
Universidade Federal de Lavras, Departamento de Ciências Florestais, CP 3037. CEP 37200-000, Lavras, MG, Brasil ${ }^{2}$ Governo do Estado de Minas Gerais, E. E. Profa Ana Letro Staacks, Av. Senador M. Campos, 1, Quitandinha, Timóteo, MG, Brasil 3Prefeitura Municipal de São Gonçalo do Sapucaí, Escola Municipal Bento Gonçalves Filho, São Gonçalo do Sapucaí, MG, Brasil ${ }_{4}^{4}$ Universidade Federal de Lavras, Departamento de Biologia, CP 3037, CEP 37200-000, Lavras, MG, Brasil.

${ }^{5}$ Universidade Federal de Lavras, Departamento de Ciências do Solo, CP 3037, CEP 37200-000, Lavras, MG, Brasil * Corresponding author: epilefsama@hotmail.com
\end{abstract}

Recebido em 19.VII.2019

Aceito em 13.VII.2021

DOI 10.21826/2446-82312021v76e2021014

\begin{abstract}
The constant management of a seed bank accelerates the environmental recovery, in an attempt to reach the reference system. That said, this research aimed to evaluate the effects of a mining area on the richness, composition, and structure of the seed bank. The hypotheses are that there is greater richness in the surroundings areas in relation to the mining pit and that composition and structure are different between mining and surroundings areas. Twenty sampling points were assessed during two seasons (dry and wet): ten within a mining pit and ten in its surroundings. There was low seedling diversity from the seed bank in the mining area and a significant difference in the species composition of seeds in relation to its surroundings. The species composition from both sites/treatments includes pioneers, bioaccumulators and phytoremediators, which are important to maximize results for the recovery of degraded mining areas.
\end{abstract}

Keywords: bioaccumulation, degraded areas, phytoremediation, recovery

RESUMO - Diferenças no banco de sementes do solo em área de mineração e adjacências: estudo de caso inserido no domínio do Cerrado. O gerenciamento de um banco de sementes acelera a recuperação ambiental para alcançar o sistema de referência. Diante disso, o objetivo desta pesquisa foi avaliar o efeito de uma área de mineração na composição e diversidade do banco de sementes. As hipóteses foram de que há maior riqueza nas áreas do entorno em relação à mina, e que a composição e estrutura são diferentes entre as áreas mineradas e arredores preservados. Vinte pontos de amostragem foram avaliados, utilizando uma espátula manual de aço inoxidável para coletar o solo durante duas estações (seca e úmida): dez dentro de uma cava de mineração e dez nos arredores. Encontramos uma baixa diversidade de plântulas do banco de sementes na área de mineração e uma diferença significativa na composição de espécies em relação às áreas do entorno. A composição de espécies de ambos os locais/tratamentos inclui pioneiras, bioacumuladores e fitorremediadores, que são importantes para maximizar os resultados para a recuperação de áreas mineradas degradadas.

Palavras-chave: áreas degradadas, bioacumulação, fitorremediação, recuperação

\section{INTRODUCTION}

Soil seed bank is the set of viable seeds in a given area (with or without vegetation) over a certain period of time (Li et al. 2012). Seed bank studies have been the focus of research throughout Brazil for different purposes, such as the edge effect, environmental indicators, and nucleation methods (Martins et al. 2008, Leal-Filho et al. 2013, Braga et al. 2016, Machado et al. 2017).

Seed banks can contain high diversity of species (Ferreira et al. 2015, Braga et al. 2016, Silva et al. 2019), providing resilience and regeneration of native species (e.g. Guimarães et al. 2012, using topsoil) and presenting high density of viable seeds (Martins 2007, Pilon et al.
2018). Thus, the use as a restoration technique (seed bank transfer) associated with the description of species richness, abundance and composition before a disturbance event of natural or man-made causes (environmental degradation) and its subsequent monitoring helps to understand the succession processes in the specific area. The seed bank transfer is such an important technique that it is used in different ways and in different morphoclimatic domains [e.g. Amazon (Leal-Filho et al. 2013), Atlantic forest (Braga et al. 2016), among others].

Seeds are usually lost due to mineral extraction. After total mineral extraction, the area undergoes a recovery process. In order to recover a given area using its previous vegetation elements, propagules of its surroundings can 
be used (Martins et al. 2008, Miranda Neto et al. 2017, Pilon et al. 2018). However, descriptive studies on these methodologies and their respective results in mining areas are still incipient.

Few studies showed that the constant management and the transposition of the seed bank of adjacent areas accelerate the recovery of the forest ecosystem (forest with similar characteristics from before mineral exploration) (Martins et al. 2008, Guimarães et al. 2012). The soil seed bank presents a successional floristic replacement property. Monaco et al. (2003) and Sandeville Jr. (2010) stated that forest sources with different successional stages increment the seed implementation in places where the soil seed bank is not sufficient.

Based on the above arguments, this study aimed to evaluate the richness, composition and structure of the soil seed bank of a mining pit and its surroundings. It is hypothesized that there is greater richness in the surroundings areas in relation to the mining pit. Moreover, the species composition and structure are different between mining and surroundings areas.

\section{MATERIAL AND METHODS}

\section{Study area}

The study area is located in the Cerrado domain, in Vazante city, northwest of the state of Minas Gerais (17²36'S $-46^{\circ} 42^{\prime} \mathrm{W}$ ), Brazil (Fig. 1). The area has an altitude of 550 meters at sea level and tropical savanna climate (Aw), with dry winter and rainy summer, according to the Köppen climatic classification (Alvares et al. 2013). The average annual temperature is $22.6{ }^{\circ} \mathrm{C}$, with a monthly average of $18^{\circ} \mathrm{C}$ in the coldest season (dry period) and $29.1^{\circ} \mathrm{C}$ in the warm season (rainy period). The average annual precipitation is $1,450 \mathrm{~mm}$, which is mainly concentrated from November to February, presenting mean monthly rainfall of less than $60 \mathrm{~mm}$ in the driest months (Antunes 1986, Brasil 1992). The natural vegetation is composed of savannas, represented by its various types and developed on soils derived from basalt (Golfari 1975). The predominant soil of the area is classified as Dystrophic Red-Yellow Latosol.

The mining area under study presents high levels of cadmium, lead and zinc, in which mineral extraction already ceased after more than 50 years of exploration. Studies related to environmental restoration and recovery have been conducted in the area (e.g. Carvalho et al. 2013, Schneider et al. 2013, Carvalho et al. 2015). Furthermore, nowadays, human action does not directly influence the presence of floristic elements. The typical vegetation of the surrounding area consists of conserved savannah, with traces of human action on the edges. It presents a thin shrub-tree layer and a continuous herbaceous layer. The study area presents several physiognomies of the Cerrado domain: from the Cerrado grassland ("Cerrado campo limpo") covering the shallowest and poorest soils of the highest elevations of the relief, to the "Cerradão" and semideciduous forests in the flat lowlands of more fertile soils (Siqueira et al. 2006).

\section{Sample design}

We evaluated two different periods: one in the rainy season (summer) and another in the dry season (winter). We sampled in these two seasons to find the maximum number of species dispersed throughout the year. The mining pit was divided into 50 blocks to select the sampling points. The surrounding vegetation areas were mapped using Google Earth ${ }^{\circledR}$, and also divided into 50 blocks of similar area to the mine. We choose randomly twenty sampling points,

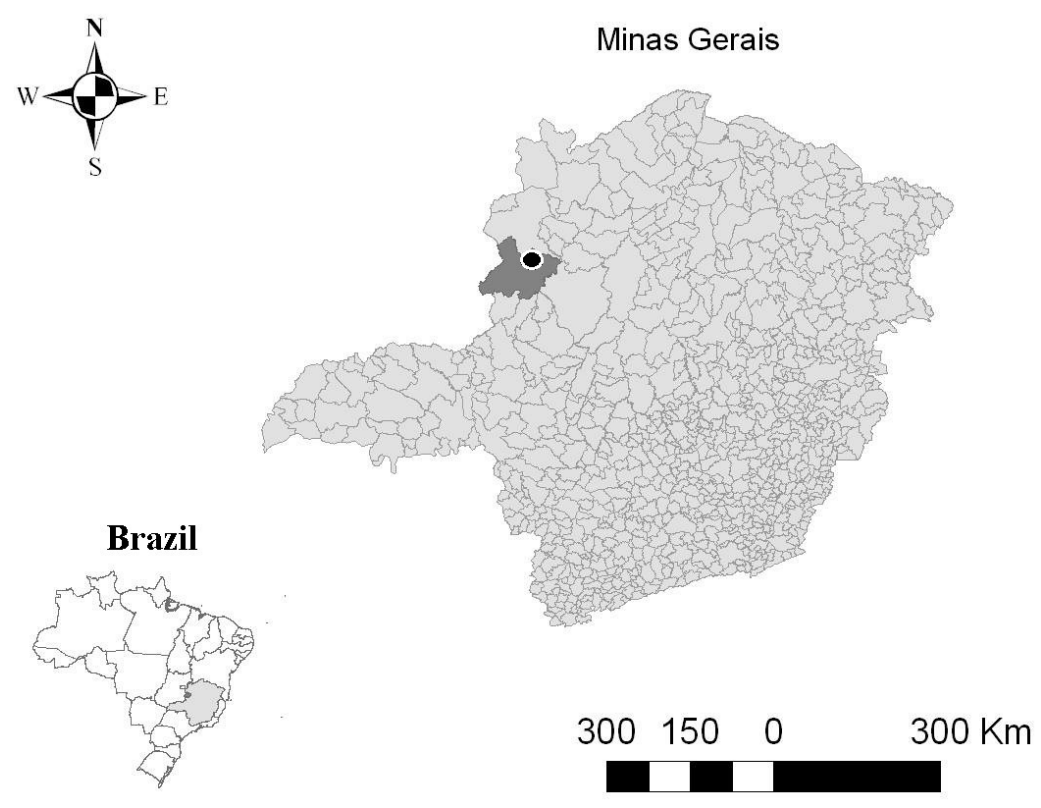

Figure 1. Location of Vazante city and study area, northwest of Minas Gerais state, Brazil. 
ten within the mining pit (Treatment 1) and ten others in its surrounding area (Control Treatment). Each sampling point was distant from each other by approximately 30 meters. At each sampling point, we collected two soil samples by at least two meters apart. The two soil samples from each sampling point constituted a single replicate for statistical testing. The surrounding areas that were used as control treatments are distant from the mining pit by nearly 50 meters.

We collected $25 \times 25 \mathrm{~cm}$ soil samples from $10 \mathrm{~cm}$ superficial layer. We collect a total of 40 soil samples (20 for each treatment), resulting in a volume of $250,000 \mathrm{~cm}^{3}$ of soil and an area of $2.5 \mathrm{~m}^{2}$. The two samples of each sampling point were homogenized and packed in plastic bags to germination. Germination was conducted in plastic trays $(44 \times 27.6 \times 7.6 \mathrm{~cm})$ and the material was irrigated every morning during 180 days.

The germinated seeds from the seed bank at the end of 180 days were quantified, and only seedlings with a minimum size of three centimeters were identified (following methodology similar to Machado et al. 2017). Life forms and dispersion syndromes followed the standard of Machado et al. (2017) and a methodology similar to Leal-Filho et al. (2013) and Braga et al. (2016).

\section{Statistical analyses}

To verify sample efficiency and rarefaction curves (to all area and separated treatments) the first-order Jackknife richness estimator (Burnham and Overton 1978) was calculated, using EstimateS 7.5 software (Cowell 2006).

The structure includes data such as abundance and composition in a spreadsheet, in which samples were expressed in the rows and the species in the columns. In each cell, there was abundance. Thus, a dissimilarity matrix was obtained by using the Bray-curtis index. From this dissimilarity matrix, a two-dimensional ordination based on a nonmetric multidimensional scaling (nMDS) was projected, and the significance of the differences between treatments was indicated by the nMDS was tested by means of a one-way analysis of similarity (ANOSIM) (Clarke 1993), with 5\% significance level.

\section{RESULTS}

Of the 20 soil replicates, six had no germination, one from the surrounding area and five from the mining pit. We found a total of 69 seedlings of 22 species belonging to 18 botanical families (Table 1), resulting in a density of 27.6 seedlings $/ \mathrm{m}^{2}$. For the surrounding area, we found 47 seedlings with a richness of 22 species. For the mining pit, 22 seedlings were found with nine species, being three species exclusive to the mining area (Calotropis procera, Leucaena leucocephala and Gomphrena claussenii). Since four species found in the vicinity of the open pit were not identified, they were morphotyped in the attempt of a future identification. Asteraceae, Malvaceae, Sapindaceae, Fabaceae and Solanaceae were the most representative families for both treatments, and the species with the highest number of germinations belong to the Solanaceae family.

The curves of species accumulation and the estimator did not reach asymptote. The first-order Jackknife estimated a richness of 35.36 species; the sampled richness represented $67.83 \%$ of the estimated richness. The curve of the richness estimator was not within the $95 \%$ confidence interval (Fig. $2 \mathrm{~A}$ e $2 \mathrm{~B})$. However a clear difference in species richness was observed between the mining pit and surrounding area (Fig. 2A).

Seed bank community structure showed a significant difference according to ANOSIM $(\mathrm{R}=0.586, \mathrm{p}<0.006)$, which can be seen by most of sampling points from surrounding areas that are in the right side of the ordination plot (Fig. 3). However, nMDS showed no visible separation for all points from each treatment in the two-dimensional ordination, possibly because some of mining pit plots are spatially close to surroundings samples (Fig. 3).

\section{DISCUSSION}

Our study showed that species richness, composition and structure of soil seed bank of mining pit areas differ significantly from surrounding areas in the Cerrado region. Most of the families and genera found in the present study are in agreement with the diversity found by Neri et al. (2011), who also found families such as Fabaceae, Asteraceae, Malpighiaceae and Rubiaceae in a study area located near the area of the present study. Nonstabilization of the species accumulation curve indicates that there are species in the seed bank that were not sampled. Nevertheless, we did not expect the stabilization of the curves due to the great diversity and environmental heterogeneity of neotropical savanna ecosystems (Cerrado) (Myers et al. 2000, Klink \& Machado, 2005).

Species diversity of the soil seed bank of the mining area and its surroundings area are considered very small when compared with other seed bank studies developed in the Cerrado domain. Ikeda et al. (2008) found 36 species for Cerrado areas that were anthropized by fire, while Melo et al. (2007) found 49 species. The results of the present study might are reflecting the great harshness caused by mining activities due to vegetation suppression interventions and subsequent use.

Gomphrena claussenii was found inside the open mining pit and it is described as phyto-remediating of different types of metals (cadmium and zinc) at high concentrations (Carvalho et al. 2013). The presence of this species in mining pits was also reported in other studies conducted in Vazante (MG) (Carvalho et al. 2013, Carvalho et al. 2015). Another species that has a similar behavior is Leucaena leucocephala; an exotic species that in association with arbuscular mycorrhizal fungi presents similar phytoremediation performance (mentioned by Schneider et al. 2013, for arsenic), therefore, common within mining areas. Calotropis procera was also present in the seed bank of the mining pit; it is an invasive species from Asia and Africa that was introduced in Brazil around 1900. 
Table 1. Germinated species in the seed bank in the Cerrado area of Vazante, northwest of Minas Gerais state, and their respective Life Forms (LF): shrub $=\mathrm{S}$, Tree $=\mathrm{T}$, Herb $=$ ER and Liana $=$ LI, Succession Classifications $(\mathrm{SC})$ : Pioneer $=$ PI and non-pioneer $=$ NP and Seed Dispersion $(\mathrm{D})$ : Anemochory $=$ ANE, Barocory $=\mathrm{BAR}$, Hydrochory $=$ HID and Zoochory $=$ ZOO.

\begin{tabular}{|c|c|c|c|c|c|}
\hline $\begin{array}{l}\text { Family } \\
\text { Species }\end{array}$ & LF & $\mathrm{CS}$ & $\mathrm{D}$ & $\begin{array}{l}\text { Mining area } \\
\text { (Treat. 1) }\end{array}$ & $\begin{array}{l}\text { Surroundings } \\
\text { (Treat. Control) }\end{array}$ \\
\hline \multicolumn{6}{|l|}{ Malvaceae } \\
\hline Sida $\mathrm{sp}$ & $\mathrm{S}$ & PI & ANE & & 1 \\
\hline Apeiba tibourbou Aubl. & $\mathrm{T}$ & PI & BAR & 1 & 11 \\
\hline \multicolumn{6}{|l|}{ Malpighiaceae } \\
\hline Mascagnia sp. & $\mathrm{S}$ & PI & ANE & & 3 \\
\hline \multicolumn{6}{|l|}{ Asteraceae } \\
\hline Asteraceae sp1. (morphotype 1) & $\mathrm{S}$ & PI & ANE & & 1 \\
\hline Asteraceae sp2. (morphotype 2) & $\mathrm{S}$ & PI & ANE & & 1 \\
\hline \multicolumn{6}{|l|}{ Rubiaceae } \\
\hline Borreria sp. & $\mathrm{S}$ & PI & ANE & 2 & 5 \\
\hline \multicolumn{6}{|l|}{ Apocynaceae } \\
\hline Calotropis procera (Aiton) W.T.Aiton & ER & PI & ANE & 1 & \\
\hline \multicolumn{6}{|l|}{ Verbenaceae } \\
\hline Duranta sp. & ER & PI & ANE & & 1 \\
\hline \multicolumn{6}{|l|}{ Celastraceae } \\
\hline Hippocratea volubilis L. & LI & PI & ANE & & 2 \\
\hline \multicolumn{6}{|l|}{ Lamiaceae } \\
\hline Hyptis sp. & ER & PI & ANE & 1 & 4 \\
\hline \multicolumn{6}{|l|}{ Fabaceae } \\
\hline Leucaena leucocephala (Lam.) de Wit & $\mathrm{T}$ & PI & HID & 1 & \\
\hline Fabaceae sp1. (morphotype 3) & $\mathrm{S}$ & PI & ANE & & 1 \\
\hline \multicolumn{6}{|l|}{ Oxalidaceae } \\
\hline Oxalis sp. & ER & PI & ANE & 1 & 6 \\
\hline \multicolumn{6}{|l|}{ Piperaceae } \\
\hline Piper arboreum Aubl. & $\mathrm{S}$ & PI & $\mathrm{ZOO}$ & & 4 \\
\hline \multicolumn{6}{|l|}{ Sapindaceae } \\
\hline Paullinia sp. & $\mathrm{S}$ & PI & & 1 & 2 \\
\hline Serjania sp. & $\mathrm{S}$ & PI & & & 1 \\
\hline \multicolumn{6}{|l|}{ Solanaceae } \\
\hline Capsicum parvifolium Sendtn. & $\mathrm{S}$ & PI & ANE & & 2 \\
\hline Solanum caavurana Vell. & $\mathrm{S}$ & PI & $\mathrm{ZOO}$ & & 3 \\
\hline Solanum sp. & $\mathrm{S}$ & PI & $\mathrm{ZOO}$ & & 1 \\
\hline \multicolumn{6}{|l|}{ Pentaphylacaceae } \\
\hline Ternstroemia brasiliensis Cambess. & $\mathrm{T}$ & NP & HID & & 2 \\
\hline \multicolumn{6}{|l|}{ Cannabaceae } \\
\hline Trema micrantha (L.) Blume & $\mathrm{T}$ & PI & $\mathrm{ZOO}$ & 1 & 2 \\
\hline \multicolumn{6}{|l|}{ Amaranthaceae } \\
\hline Gomphrena claussenii Moq. & $\mathrm{E}$ & PI & $\mathrm{ZOO}$ & 6 & \\
\hline Pteridophyte sp1. & ER & PI & ANE & & 1 \\
\hline
\end{tabular}

It is highly resistant to varied environmental conditions and expanded its distribution to different Brazilian morphoclimatic domains, such as Cerrado (Fabricante et al. 2013). Its ability to colonize new areas is related to his preference for ferruginous soils (Oliveira et al. 2009), as it was found in the study area. It is worth emphasizing that these exotic species are invasive. Degraded areas are easily occupied by exotic species and including such species in a recovery technique can cause an additional problem, biological invasion. Biological invasions are threats to biodiversity (Meffe \& Carroll 1997) and tend to get worse (Westbrooks 1998). Invasive species are highly efficient in competing for resources and can cause serious environmental and economic damage (Daehler 2003). 

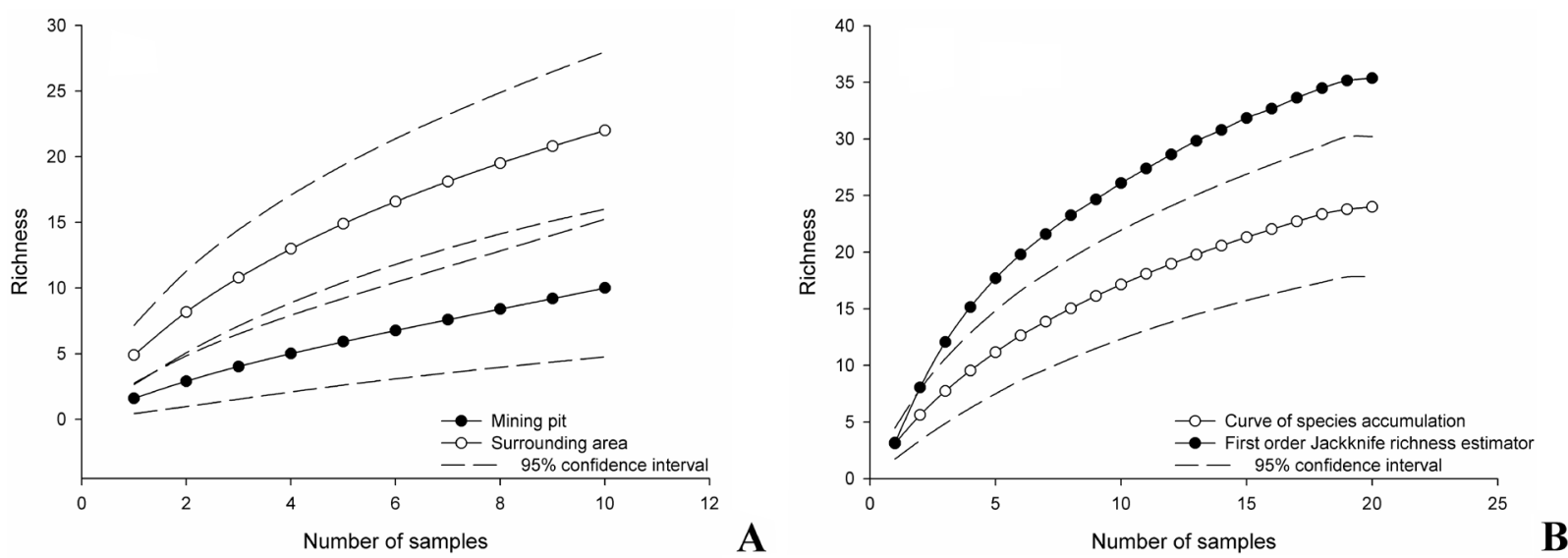

Figure 2. Curves of species accumulation for the seed bank of Vazante city, northwest of the state of Minas Gerais, Brazil. A. Accumulation curve for the seed bank and confidence interval in a mining area and surrounding area separated; B. Accumulation curve for the seed bank, confidence interval and first-order Jackknife richness estimator in a mining area and surrounding area together.

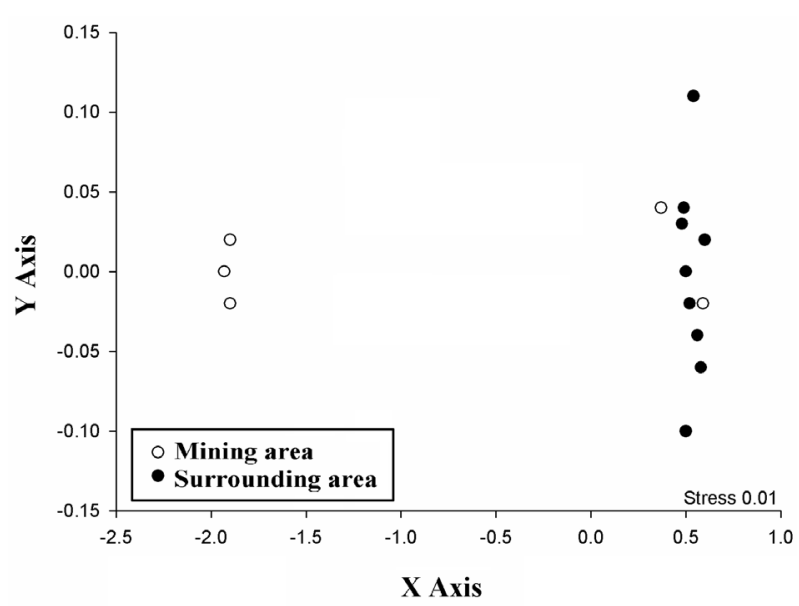

Figure 3. Two-dimensional ordination diagram based on the nonmetric multidimensional scaling (nMDS) for species density of the seed bank from a mining pit and surrounding areas in Vazante municipality, northwest of the state of Minas Gerais, Brazil.

The composition of the seed bank was dissimilar between areas, and richness was approximately twice as large in the surrounding area when compared with the mining pit. In these species composition, we found several pioneer species in the seed bank (Caldato et al. 1996, Baider et al. 1999, Monaco et al. 2003, Soares and Almeida 2011), which can favor an accelerated regeneration that is necessary for restoration. Sampled pioneer species are mostly herbaceous and shrub (Souza et al. 2006, Calegari et al. 2013, Machado et al. 2017), commonly found in seed banks of degraded areas, where several characteristics, such as dispersion ability, favor their dominance (Braga et al. 2016). The seed dispersion by anemochory was the main strategy found in the area, which is relatively common in number and proportion in dry habitats (Howe and Smallwood 1982). Strong winds favor the dispersion of anemochoric species (Howe and Smallwood 1982). In addition, wind-dispersed seeds tend to be produced in the dry season (Howe and Smallwood 1982), which justifies the sampling of seed bank in different seasons. For Solanum, Piper and other zoochoric species, the average dispersion of them by vertebrates can reach up to $70 \%$ to $90 \%$ (Willson et al. 1989) and the consumption of fruits (frugivory) by birds is a fundamental step in the reproduction of most tropical plants (Herrera 1994), such as Trema micrantha (L.) (Andreani et al. 2014).

The transpositions of the seed bank have been shown to be an efficient technique for the restoration of modified and degraded areas (Leal-Filho et al. 2013, Pilon et al. 2018) such as mining pits (e.g. our study area). Considering the seed banks of nearby Cerrado area in an intermediate stage of human action, it is the most suitable for restoring areas with little or no vegetation, and the soil would not influence, since the physical-chemical attributes are similar for the donors and receiving areas (Amaral et al. 2017). The available diversity in a donor area nearby the degraded one is the result of years of deposition of relict and resistant species. They are able to withstand environmental adversities (such as intense heat or excessive rainfall, among other natural events) that might happen along the successional process of environmental restoration. Therefore, species present might have favorable characteristics for the regeneration and recovery of mining areas. However, it is recommended the use of other methodologies in order to maximize the results, for example, with the installation of artificial perches (Melo 1997), planting native species with zoocoric dispersion syndrome (Guimarães 2008, Garcia et al. 2009), dense planting of seedlings (Guimarães 2008), spreading of litter (Gisler 1995), among others. More research, similar to Alday et al. (2009), focusing on soil seed banks of mining areas and their surroundings ought to be conducted in order to quantify and analyze the efficiency of environmental restorations over time. 
Monaco et al. (2003) and Sandeville Jr. (2010) mentioned the importance of nearby vegetation sources for the increase of seed rain in locations where the seed bank is not sufficient to recompose an altered system. Therefore, the protection of the surrounding areas nearby the open pit can favor recovery and even the emergence of arboreal species.

We concluded that the soil seed bank from the mining pit presents reduced richness when compared to adjacent remnant areas, while the composition and structure of the samples includes pioneer (fast-growing) species and some species that present high capacity for bioaccumulation and phytoremediation. The composition and structure of the soil seed bank from adjacent areas included pioneer and non-pioneer species, with seed dispersion related mostly to anemochory and zoochory.

\section{ACKNOWLEDGEMENTS}

The authors gratefully thank the editor Sandra Muller for her efforts and the anonymous reviewers who made valuable contributions and made the work substantially improved. The authors also thank the Conselho Nacional de Desenvolvimento Científico e Tecnológico (CNPq), Fundação de Amparo a Pesquisa do Estado de Minas Gerais (FAPEMIG), and Coordenação de Aperfeiçoamento de Pessoal de Nível Superior (CAPES) for the scholarships provided to some of the authors and for the approved project.

\section{REFERENCES}

Alday, J. G., Marrs R. H. \& Martínez-Ruiz, C. 2009. Soil seed bank formation during early revegetation after hydroseeding in reclaimed coal wastes. Ecological Engineering 35(7):1062-1069.

Alvares, C. A., Stape, J. L., Sentelhas, P. C., Gonçalves, J.L.M. \& Sparovek, G. 2013. Climate classification map for Brazil. Meteorologische Zeitschrift Journal 22(6):711-728.

Amaral, L. A., Pereira, I. M., Silva, M. A. P. D., Oliveira, M. L. R. D., Machado, E. L. M., \& Laia, M. L. D. 2017. Use of topsoil for restoration of a degraded pasture área. Pesquisa Agropecuária Brasileira 52(11):1080-1090.

Andreani, D. V. M., Macedo, M., \& Massavi, M. 2014. Aves como potenciais dispersoras de Trema micrantha (L.) Blume (Cannabaceae) em um fragmento florestal no estado de Mato Grosso 180.

Antunes, F.Z. 1986. Caracterização climática do Estado de Minas Gerais: Climatologia agrícola. Informe Agropecuário 12(138):9-13.

Baider, C., Tabarelli, M. \& Mantovani, W. 1999. Banco de sementes de um trecho de Floresta Atlântica Montana (São Paulo, Brasil). Revista Brasileira de Biologia 59(2):319-328.

Braga, A.J.T., Borges, E.E.L. \& Martins, S.V. 2016. Seed bank in two sites of Semideciduous Seasonal Forest in Viçosa, Minas Gerais. Revista Árvore 40(3):415-425.

Brasil. 1992. Normais climatológicas (1961 - 1990). Ministério da Agricultura e Reforma Agrária e Departamento Nacional de Meteorologia, Brasília. 84p.

Burnham, K.P., Overton WS. 1978. Estimation of size of a closed population when capture probabilities vary among animals. Biometrika 65:625-633.

Caldato, S.L., Floss, P.A., Croce, D.M. \& Longhi, S.J. 1996. Estudo da regeneração natural, banco de sementes e chuva de sementes na reserva genética Floresta de Caçador, SC. Ciência Florestal $6(1): 27-38$.
Calegari, L., Martins, S.V., Campos, L.C., Silva, E. \& Gleriani, J.M. 2013. Evaluation of soil seeds bank for forest restoration in Carandaí, MG. Revista Árvore 37(5):871-880.

Carvalho, M.T.V., Amaral, D.C., Guilherme, L.R.G. \& Aarts, M.G.M. 2013. Gomphrena claussenii, the first South-American metallophyte species with indicator-like $\mathrm{Zn}$ and $\mathrm{Cd}$ accumulation and extreme metal tolerance. Frontiers in Plant Science 4:1-10.

Carvalho, M.T.V., Pongrac, P., Mumm, R., Arkel, J. Van., Aelst, A. Van., Jeromel, L., Vavpetič, P., Pelicon, P. \& Aarts, M.G.M. 2015. Gomphrena claussenii, a novel metal-hypertolerant bioindicator species, sequesters cadmium, but not zinc, in vacuolar oxalate crystals. New Phytologist 208(3):763-775.

Clarke, K.R. 1993. Nonparametric analysis of changes in community structure. Australian Journal Ecology 18:117-143.

Cowell RK. 2006. Estimates: statistical estimation of species richness and shared species from samples, version 7.0, User's Guide and application. University of Connecticut, USA. Available at http:// viceroy.eeb.uconn.edu/estimates. Accessed on 23 Jan 2014.

Daehler, C. C. 2003. Performance comparisons of co-occurring native and alien invasive plants: Implications for Conservation and Restoration. Annual Reviews 34:183-211.

Fabricante, J. R., Oliveira, M. N. A. D. \& Siqueira Filho, J. A. D. 2013. Aspectos da ecologia de Calotropis procera (Apocynaceae) em uma área de Caatinga alterada pelas obras do Projeto de Integração do Rio São Francisco em Mauriti, CE. Rodriguésia 64(3):647-654.

Ferreira, M. C., Walter, B. M. \& Vieira, D. L. 2015. Topsoil translocation for Brazilian savanna restoration: propagation of herbs, shrubs, and trees. Restoration ecology 23(6):723-728.

Garcia, L.C., Barros, F.V. \& Lemos-Filho, J.P. 2009. Fructification phenology as an important tool in the recovery of iron mining areas in Minas Gerais, Brazil. Brazilian Journal of Biology 69(3):887-893.

Gisler, C.V.T. 1995. Uso da serapilheira na recomposição da cobertura vegetal em áreas mineradas de bauxita, MG. Dissertação $146 f$. Universidade de São Paulo, São Paulo.

Golfari, L. 1975. Zoneamento ecológico do estado de Minas Gerais para reflorestamento. Série Técnica, 3. PNUD/FAO/IBDF, CPFRC, Belo Horizonte. $65 \mathrm{p}$.

Guimarães, J.C.C. 2008. Reabilitação de minas de bauxita em florestas nativas: "método tradicional" versus "método ecológico". Informe Agropecuário 29(244):30-33.

Guimarães, J.C.C., Magno-Junior, J., Alecrim, E., Campos, C.C.F. \& Machado, F.S. 2012. Avaliação dos aspectos e impactos ambientais decorrentes da mineração de bauxita no sul de Minas Gerais. Enciclopédia Biosfera 8:321.

Herrera, C. M., Jordano, P., Lopez-Soria, L. \& Amat, J. A. 1994. Recruitment of a mast fruiting, bird dispersed tree: bridging frugivore activity and seedling establishment. Ecological monographs 64(3):315-344.

Howe, H. F. \& Smallwood J. 1982. Ecology of seed dispersal. Annual Review of Ecology and Systematics 13:201-228.

Ikeda, F.S., Mitja, D., Vilela, L. \& Silva, J.C.S. 2008. Banco de sementes em cerrado sensu stricto sob queimada e sistemas de cultivo. Pesquisa Agropecuária Brasileira 43(6):667-673.

Klink, C.A. \& Machado, R.B. 2005. Conservation of the Brazilian cerrado. Conservation biology 19(3):707-713.

Leal-Filho, N., Rodrigues dos Santos, G. \& Leme Ferreira, R. 2013. Comparando técnicas de nucleação utilizadas na restauração de áreas degradadas na Amazônia brasileira. Revista Árvore 37(4):587-597.

Li, Y.Y., Dong, S.K., Wen, L., Wang, X.X. \& Wu, Y. 2012. Soil seed banks in degraded and revegetated grasslands in the alpine region of the Qinghai-Tibetan Plateau. Ecological Engineering 49:77-83.

Machado, F.S., França, A.C.M., Santos, R.M., Borem, R.A.T. \& Guilherme, L.R.G. 2017. Influence of edge effect on soil seed bank of a natural fragment in the Atlantic Forest. Iheringia Serie Botânica 72:247-253.

Martins, S.V. 2007. Recuperação de matas ciliares. Aprenda Fácil, Viçosa. $255 \mathrm{p}$.

Martins, S.V., Almeida, D.P.D., Vaz Fernandes, L. \& Maciel Ribeiro, T. 2008. Banco de sementes como indicador de restauração de uma área degradada por mineração de caulim em Brás Pires, MG. Revista Árvore 32(6):1081-1088. 
Meffe, G. K. \& Carroll, C. R. 1997. Principles of conservation biology. Sinawer Associates, Sunderland. 729p.

Melo, A.C.G, Durigan, G. \& Gorenstein, M.R. 2007. Efeito do fogo sobre o banco de sementes em faixa de borda de Floresta Estacional Semidecidual, SP, Brasil. Acta Botânica Brasílica 21(4):927-934.

Melo, V.A. 1997. Poleiros artificiais e dispersão de sementes por aves em uma áreade reflorestamento, no Estado de Minas Gerais. Dissertação 39f. Universidade Federal de Viçosa, Viçosa.

Miranda Neto, A., Martins, S. V., Silva, K. D. A., Lopes, A. T., \& Demolinari, R. D. A. 2017. Banco de sementes em mina de bauxita restaurada no Sudeste do Brasil. Floresta e Ambiente 24:e00125414.

Monaco, L.M, Mesquita, R.C.G. \& Willianson, G.B. 2003. Banco de sementes em uma floresta secundária amazônica dominada por Vismia. Acta Amazonica 33(1):41-52.

Myers, N., Mittermeier, R. A., Mittermeier, C. G., Da Fonseca, G. A., $\&$ Kent, J. 2000. Biodiversity hotspots for conservation priorities. Nature 403(6772):853.

Neri, A.V., Soares, M.P., Neto, M., Alves, J.A. \& Dias, L.E. 2011. Espécies de Cerrado com potencial para recuperação de áreas degradadas por mineração de ouro, Paracatu-MG. Revista Árvore 35(4):907-918.

Oliveira, S. H. F., Negreiros, D., Fernandes, G. W., Barbosa, N. P. U., Rocha, R. \& Almeida-Cortez, J. S. 2009. Seedling growth of the invader Calotropis procera in ironstone rupestrian fi eld and seasonally dry forest soils. Neotropical Biology and Conservation 4:69-76.
Pilon, N. A. L., Buisson, E. \& Durigan, G. 2018. Restoring Brazilian savanna ground layer vegetation by topsoil and hay transfer. Restoration Ecology 26(1):73-81.

Sandeville Jr. E. 2010. A dinâmica natural das florestas. Paisagem e Ambiente 27:55-70.

Schneider, J., Labory, C. R. G., Rangel, W.M., Alves, E. \& Guilherme, L. R. G. 2013. Anatomy and ultrastructure alterations of Leucaena leucocephala (Lam.) inoculated with mycorrhizal fungi in response to arsenic-contaminated soil. Journal of Hazardous Materials 262:12451258 .

Silva, K. D. A., Martins, S. V., Miranda Neto, A., \& Lopes, A. T. 2019. Soil Seed Banks in a Forest Under Restoration and in a Reference Ecosystem in Southeastern Brazil. Floresta e Ambiente 26(4):e20190047.

Siqueira, A. D. S., Araújo, G. M. D. \& Schiavini, I. 2006. Caracterização florística da Reserva Particular do Patrimônio Natural (RPPN) Fazenda Carneiro, Lagamar, MG, Brasil. Biota Neotropica 6(3):bn00906032006.

Soares, R. Z. L. \& Almeida, V. P. 2011. Banco de sementes da Floresta Estacional às margens do Reservatório de Itupararanga, VotorantimSP. Revista Eletrônica de Biologia 4(2):53-72.

Souza, P. A., Venturin, N., Griffith, J. J. \& Martins, S. V. 2006. Evaluation of a seed bank contained in the litter of a forest fragment envisaging the recovery of degraded areas. Revista Cerne 12(1):56-67.

Westbrooks, R. 1998. Invasive plants: changing the landscape of America. Fact Book, Washington, DC. 109 p. 